\title{
Trends in the Socioeconomic Achievement of the University Educated: A Status Attainment Model Interpretation*
}

\author{
JOHN C. GOYDER**
}

\begin{abstract}
The paper examines the con tribution the sociologist's status attainment model makes towards comprehending reasons for the decline, since the mid 1960's, in the economic prospects of university graduates. The assumptions of the model are compared with those underlying an economist's labour market approach, in which explanations are phrased in terms of aggregate demand and supply for the university educated. Tested in the paper is the hypothesis that decline in background endowments among university graduates, a consequence of the policy commitment to democratize access to Canadian universities, accounts for some of the downward trend in the level of job obtained by graduates entering the labour market. The sta tistical analysis us es data from Ontario and Canada-wide surveys, and finds that changes in father's mean status explain only a small part of the drop in son's first job status. The mod el suggests that deterioration in university completion rates can account for more of the decline.
\end{abstract}

\section{RÉSUMÉ}

Le travail examine la contribution que le modele de l'accession au rang social fournit par le déclin des perspectives économiques des diplômés universitaires dès la moitié des années 60. On compare les hypothèses du modèle avac celles qui servent de base aux économistes pour l'étude du marché de travail, dans laquelle les explications sont formulées en terme d'offre et demande collective des universitaires. On test l'hypothèse selon laquelle la baisse du niveau général des universitaires, conséquence de la politique adoptée de démocratisation de l'accès aux études universitaires au Canada. explique une certaine

* This is part of a research programme supported by a grant from the SSHRC. I am indebted to Edward Harvey, who permitted me to use his Ontario survey: to James Curtis, Neil Guppy, and Peter Pineo, for their comments on the paper; to Wayne Thirsk, for bibliographic advice: and to Jean Leiper and Christine Kluck Davis for research assistance. The paper was prepared, in part, while the author was supported by a Canada Council Leave Fellowship.

** Department of Sociology, University of Waterloo. 
tendance à la ba isse du niveau de travail obtenu par les diplômés qui s'introduisent sur le marché de travail. L'analyse statistique emploie des données obtenues en Ontario et partout au Canada et concht que des changements dans le statut moyen du père n'explique qu'en partie la baisse de niveau du premier emploi du fils. Le modèle suggère que la détérioration des études universitaires menées à bien explique davantage ce déclin.

\section{MODELS OF ECONOMIC LIFE CHANCES}

The under-employment of graduating university students is one of the social issues of earlier times (e.g., Sorokin, 1964 [1927]: 201) that has, during the 1970's, again become controversial. In Canada, economists, sociologists, and e duca tors have examined matters such as unive rsity enrollment fore casts (Zsigm ond and Wenaas, 1970; Zsigmond, 1976; Handa and Skolnik, 1972) graduates' average starting salaries (e.g., Manpower and Imm igration, 1976; Beach, 1977), their prospects for occupational mobility from father's status (Ha rvey and Charner, 1975), and changes in attitudes towards education and work (e.g., Harvey, 1974; Harvey and Lennards, 1970).

Most have approached the problem from the perspective of demand and supply for the highly educated in the labour market. The work of the American economist R.B. Freeman is representative $(1971,1975,1976$, and clsewhere). How, his an alysis inquires, does the return on "human capital" vary a ccording to the in terplay between the quantity of graduates the universities produce yearly and the number and types of openings the economy requires each recruiting season? Supply and demand are linked, for Freeman (1976: 52). Students make informed decisions about investments in education, seeking out fields where vaca ncies are plentiful and salaries high. The market demand for the highly educated is, in turn, thought to rise if the salaries commanded by graduates decline. Freeman uses a "cobweb feedback system" to accommodate the fact that a three or four year lag must ensue between a student's career decision upon commencing a university education and the state of the employment market entered upon graduation. High enrollments in academic specialities leading to well salaried occupations set into motion an increase in sup ply that subseque ntly forces salaries to diminish, as graduates make their way through university and into the employmen $t$ market. The model proves to closely fit observed trends.

Such an interpretation of trends in SES achievement among the inniversity educated has, like all theoretical modeis, certain simplifying assumptions. Career decisions are taken to be voluntary and guided primarily by the profit motive. One university graduate is seen to be much like another so that a single rate of return on investment in human capital may be computed. Indeed, Freeman uses variables me asured at the aggregate level, such as degrees granted per year and average starting salaries. The claim is not that there is pure competition in the labour market. He notes, for instance, that doctors have "perhaps the strongest trade union in the United States. It has virtually complete control 
over the supply of doctors, and actively uses this control to restrict supply and raise doctors' incomes." (1976: 118). The model does imply pure competition, however, in the sense that market imperfections are only treated discursively and are not incorporated into the statistical analysis as variables. By concentrating attention upon overall demand and supply the model seems almost inevitably insensitive to the non-market factors that may actually cause the market equilibrium.

The approach to be followed in the analysis described herein is to adopt some different assumptions about the allocation of university graduates into occupations and, recognizing that these too are no more than working simplifications, examine the potential of an alternative theoretical model to interpret the trend towards under-employment among university graduates. Our argument will be that the sociologist's preoccupation with characteristics of individuals uncovers a class of variable germane to the problem of university graduates but absent from the labour market economist's analysis.

The intelle ctual traditions of North American sociology have been said to emphasize the individual (Wolff, 1959: 581) over macro units of analysis. Voluntary choice in the occupational realm, sociologists assume, is limited. Intelligence, aspirations, and the resources that the family can provide all constrain career decisions. And, the tradition has been to regard university education as a social attribute, having implications for lifestyle and access to networks, as well as simply a form of investment in formal market. able skills (Porter, 1965). A "status attainment" model of socioeconomic achievement has been developed by sociologists working within these assumptions (e.g., Blau and Duncan, 1967; Duncan et al., 1972; Featherman and Hauser, 1977). The model, Horan (1978) has recently pointed out, is explicitly individualistic. ${ }^{1}$ It focuses upon the biographical characteristics of individuals and only recently has some cognizance of the economist's approach been made by incorporating into the model contextual variables such as labour market segmentation (Beck, et al., 1978). While a demand/supply analysis emphasizes change over time in occupational rewards, sociologists have viewed occupations as forming a stable prestige ordering, found to be virtually unchanged from decade to decade (Hodge et al., 1966).

It is this conception of an unchanging hierarchy of status that renders plausible a model stressing the personal endowments individuals bring into the labour market. Attention is not upon the occupational role, as dependent variable, but upon the social characteristics of incumbents of roles. The model has proved apposite to the analysis of differential achievement among sociologically important groups. If blacks in the United States, or French-Canadians in Canada, are found on average to hold low SES the model permits a partitioning of the ine quality into a part due to mean differences in the background characteristics possessed by each group versus the portion attributable to between group differences in the "process of status allocation" (Featherman and Hauser, 1976: 647) describing how endowments are thought to "convert" (1976: 646) into socioeconomic outcomes.

In sum, where the labour market economist's inclination is to analyze at the aggregate level, using macro variables, the sociologist's is to use biographical variables in surveys of individuals. As the economist's approach sensitizes to the shifting in economic rewards consequent to labour market re-adjustments the sociologist emphasizes peoples' movements over a scale thought to capture an underlying stable graduation of social 
status. And, if the economist's conceptual strength is stress upon the individual's assessments of the contemporary market the sociologist's may be the theoretical richness of a model calling upon predictors that can precede a contemporary reading of status by a full generation. ${ }^{2}$

\section{PREDICTIONS FROM THE STATUS ATTAINMENT MODEL}

Educational policy in Canada since the Second World War provides a compelling setting in which to test the importance of the status attainment model for comprehending trends in SES levels among the university educated. The university system in this country was egregiously underdeveloped before the War and sociologists such as Porter (1965) began in the 1950's to call attention to the need for increased government spending on postsecondary education. The decision to expand the Canadian universities was a commitment to a social policy as well as a market response to high demand for university level labour. It was felt that the Canadian university structure was elitist, that to have a small corps of graduates from middle class families, augmented by university educated immigrants from the U.K., was undemocratic and harm ful to the social development of the nation (Porter, 1965; Forcese, 1975: 95-81; Synge, 1976: 406-408). Enrollments rose in both Canada and the United States, during the post-war years, but the Canadian system started from a smaller base and expanded at the faster rate (Harvey, 1974: 46; Ostry and Zaidi, 1979: 125). One expects a trend, in this country at least, for the social class composition of the university student population to have become more mixed over time. It is such changes that the status attainment model is sensitive to: the model predicts that an increasing proportion of working class fathers of the university educated represents a systematic decline in background endowments, likely to result in a diminution in mean SES among graduates. ${ }^{3}$

The logic of the status attainment model generates a second order question about trends in prospects for the university educated. Emphasis has been placed, by those working with the model, upon across group comparisons of the importance of variables in the model. To discover, for instance, that the relative importance of variables predicting occupational status among American blacks has converged over time with the model for whites would be viewed as important even if the overall margin in mean status between the groups had not changed (Featherman and Hauser, 1976: 623). In the same sense, it may be said that change in the form of a model of biographical factors in status attainment is germane in its own right to assessments of the fortunes of the university educated.

Our hypothesizing here conjectures that the form of the attainment model is related to market level factors: When the market for highly educated labour is tight, the importance of family background variables is expected to be augmented. Phrased in the language of occupational mobility analysis, the proposition is that intergenerational mobility among the university educated is greatest under a favourable market. Rationale for the hypothesis lies in the argument that under a seller's labour market it may be sufficient, for ensuring continuity in status, if middle class families provide university education for their children but when the market tightens a more active intervention becomes necessary. This could include supporting children while they wait for an appropriate job opening, using family contacts to the maximum, or subsidizing re-training. 
The paper will proceed by testing first the hypothesis to do with mean SES levels among cohorts of university graduates. Then, the hypothesis concerning strength of family ascription will be assessed.

\section{PROCEDURES}

Data from two surveys are used. One, known as the Canadian Mobility Study, is a large $(\mathrm{N}=45,000)$ national level sample of men and women aged 18 and over. Collected in July 1973 for a group of sociologists from Carleton, McMaster, and Waterloo, fieldwork was conducted by Statistics Canada and the survey was enumerated as a supplementary "drop off" questionnaire included with the regular monthly Labour Force Survey. The mobility questionnaire contained seven pages of questions concerning variables such as education, occupation, income, and a variety of social background characteristics.

The questionnaire design is similar in scope to the national American mobility surveys collected in 1962 (Blau and Duncan, 1967) and 1973 (Featherman and Hauser, 1977) by the U.S. Census Bureau. The overall completion rate on the Canadian survey was $78 \%$; the survey contains 3,082 males reporting at least some university education and 18,735 with no university. ${ }^{4}$ Further details about the sample are contained in Boyd and McRoberts (1974) and Boyd, Goyder, Jones, McRoberts, Pineo, and Porter (forthcoming).

The other survey was collected by Edward Harvey and sampled from the 1960, 1964, 1968 , and 1972 graduation years of four Ontario universities. The survey is valuable for its accurate measurement of year of graduation. This can only be estimated, from birthdate, in the national mobility study. The Ontario survey also contains questions abou $t$ the educational career, asking details about such matters as degree and programme, that were not posed in the larger study. Lacking in the Ontario survey is the full age range of respondents found in the national data, and a sample of the non-university educated against which graduates' SES attainment in different years can be compared. Harvey has reported details on his survey in various publications (e.g., 1974).

Longitudinal studies of trends in SES attainment, using internal age cohort analysis of a single sample, are confronted by the problem that current occupation or income level is partially a function of respondent's career stage. This is measured by respondent's age, the same variable that must be used to establish historical period. Since the two attributes cannot be disentangled when they are represented by a single indicator, inferences about historical trends are on the soundest footing when SES at some fixed point in the career can be examined. First job meets these specifications because it is entered at roughly the same age by all. Thus, the analysis reported here emphasizes first job attainment although some of the relationships are re-analyzed using current status. It has some times been felt that first occupation is a transitory status that may not have a great deal to do with subsequent achievements. Indeed, to study "intragenerational mobility" is to make this assumption. First occupation is nonetheless important in the present context because much of the purpose of the paper is to interpret the fortunes of recent graduates. Among this generation, current occupation is unlikely to differ greatly from first occupation. Further, it is the depreciated first job status earned by the university degree that has aroused the sense of concern among the public. ${ }^{5}$

In the national sample, the university educated include those reporting "some" university. Only full graduates were sampled in the Ontario survey. Computations are confined 
to males. The status attainment model for females is known to take a peculiar form (Boyd., et al., forthcoming), father's SES having little to do with respondent's occupation. Further, in trend analysis historical changes in the labour force participation rate for females, coupled with life cycle effects on their participation (Ostry, 1968) would render interpretations difficult.

\section{MEAN FIRST OCCUPATIONAL SES AMONG THE UNIVERSITY EDUCATED}

The success of the attempt during the 1960's to democratize access to Canadian universities is not universally conceded by writers on education. Some (e.g., Breton, 1972; Porter, Blishen, and Porter, 1973; Gilbert and McRoberts, 1977) have stressed the psychological barriers discouraging working class high school graduates from entering university. These impediments, it has been argued, have persisted well into the era of the expanded university. Forcese (1975: 77-8) compared the 1951 distribution of university students' fathers' Blishen scores with more recent data on parents' education and income level and, although the comparison was not exact, argued that: "there is little change in pattern". Pike (1970: 55-63) studied the school and university retention rates of those aged 14-24 in 1951 versus those 15-24 in 1961. A tabulation by father's occupational SES showed increased education participation for all social class levels. Changes in the class structure of the population in high school and university were found, at best, to be slight and equivocal.

The data that the Ontario survey can bring to bear on this question appear in Table 1, in the form of mean father's occupational prestige and years of education, and mean years of education for university graduates from each of the four years sampled. Father's occupation dropped slightly between 1960 and 1964, falling more sharply after 1964 . The overall decline, from a mean of 54.6 in 1960 to 50.5 in 1972, amounts to some 4 prestige points. While not large, a margin of this size is given perspective when one realizes that it is greater than the difference in mean (current) occupational SES between French and English-speaking Canadians. This inequality, totalling some $3 \frac{1 / 2}{2}$ points on the Blishen scale (see Boyd, et al., forthcoming) has, of course, been viewed as one of the important social problems in Canadian society. Mean father's education declined by almost one year between 1960 and 1968, recovering slightly by 1972. Respondent's education, the third item tabulated in Table 1 , reflects the incidence of further education by those receiving their undergraduate degrees in each sample year. The scoring system, devised from the national survey, considers the undergraduate degree as equivalent to 16 years and averages graduate work out to 18.5 years. The acquisition of graduate training has, Table 1 reveals, declined in each year.

How important has the decline in the level of background endowments been in accounting for the decline in first job status among university graduates? An answer appears in Table 2, where the actual mean prestige of graduates' first jobs is compared with estimates predicted from a regression equation linking first job with the three factors described above and two further variables to be described later. The actual pattern is striking, and has been described elsewhere (Harvey, 1974; Tepperman, 1975: 195). The mean prestige of the jobs first taken by graduates in 1960 and 1964 rounds off in each year to 65 points; by 1968 the mean had dropped by 5 points; by 1972 the decline 


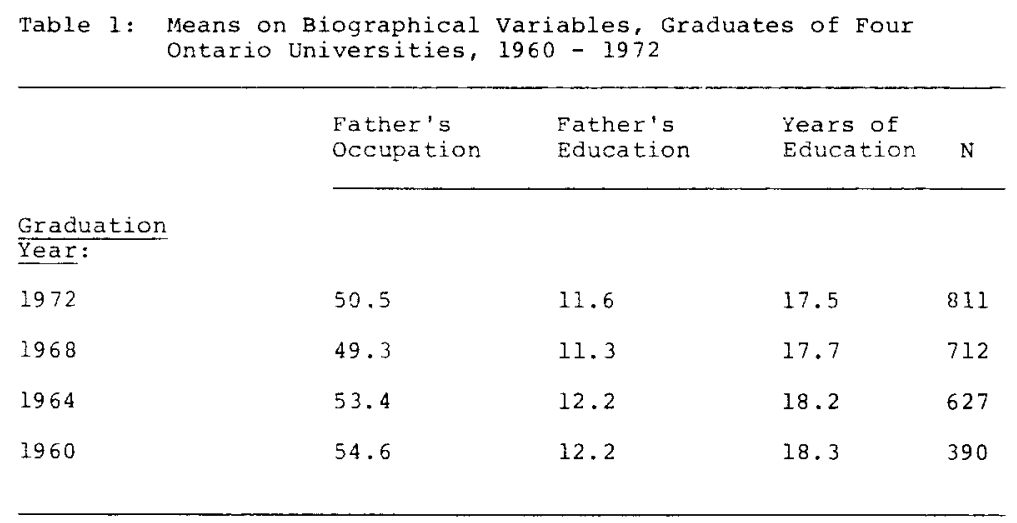

Note: For scoring details, see Table 2 .

since 1960 had reached over 10 points, this cohort of graduates showing an average prestige score of only 54.5 .

A distinction between varieties of biographical variable will be made, as predictions of first occupation prestige are attempted. Father's education and occupation can be considered "ascriptive" (e.g., Cuneo and Curtis, 1975) factors over which sons have scarcely any control. The acquisition of education, it is argued in the attainment literature, is known in the general population to be partially related to parental SES but determined also by such factors as intelligence, interests, and assessments of likely returns. In the sample of Ontario graduates, the question is of further education, at the post-graduate level. Decisions to undertake graduate study are not independent of parental SES $(r=.12$, years by father's occupation) but, from Freeman (1976: 52-56), such decisions are also tied to assessments of market conditions. It is at junctures such as this where it is apparent that market level factors and biographical variables are not fully separable. Our resolution of the dilemma will be to present initially predictions of first job prestige based solely upon father's education and occupation. In the second prediction entered into Table 2 graduate education is included in the equation. A third prediction takes account of the mix of types of degree and fields of study. These factors, like years of education, are biographical variables that may be caused in part by market factors.

The prediction confined to strictly ascriptive variables can be seen (Table 2) to capture only an overtone of the actual pattern. ${ }^{6}$ Only 0.5 of the 4.8 point drop in first job prestige between 1960 and 1968 is accounted for by the decline in parental endowments. One factor behind the weak prediction is the fact that the effects of father's education are redundant (seen in the small negative value for this factor, in the equations recorded in Table 2) once father's occupation is known. The further steep decline in first job status after 1968 escapes the notice of the model entirely, the prediction being a small improvement in first job scores. In the model having a scoring for graduate education the prediction is closer to reality; nearly half of the actual 10 point drop in first job prestige between 1960 and 1972 can be comprehended when the values for father's education and occupation, plus respondent's years of education, are substituted into the equation.

The third prediction, adding degree type and field of study to the equation, adds no 
Table 2: Observed and Predicted First Occupation Prestige, Graduates of Four Ontario Universities, 1960-72.

\begin{tabular}{|c|c|c|c|}
\hline \multirow[t]{2}{*}{ Observed } & \multicolumn{3}{|c|}{ Predicted } \\
\hline & $\begin{array}{l}\text { Father's Educ. } \\
\text { Father's Occ. }\end{array}$ & $\begin{array}{l}\text { Father's Educ. }{ }^{* *} \\
\text { Father's Occ. } \\
\text { Yrs. Educ. }\end{array}$ & $\begin{array}{l}\text { Father's Educ. } \\
\text { Father's Occ. } \\
\text { Yrs. Educ. } \\
\text { Degree-type } \\
\text { Field }\end{array}$ \\
\hline
\end{tabular}

\section{Graduation}

\begin{tabular}{lllll}
1972 & 54.5 & $60.2^{-}$ & 58.2 & 58.1 \\
1968 & 60.0 & 60.1 & 59.3 & 59.4 \\
1964 & 65.2 & 60.5 & 62.2 & 62.4 \\
1960 & 64.8 & 60.6 & 62.8 & 62.7 \\
\hline
\end{tabular}

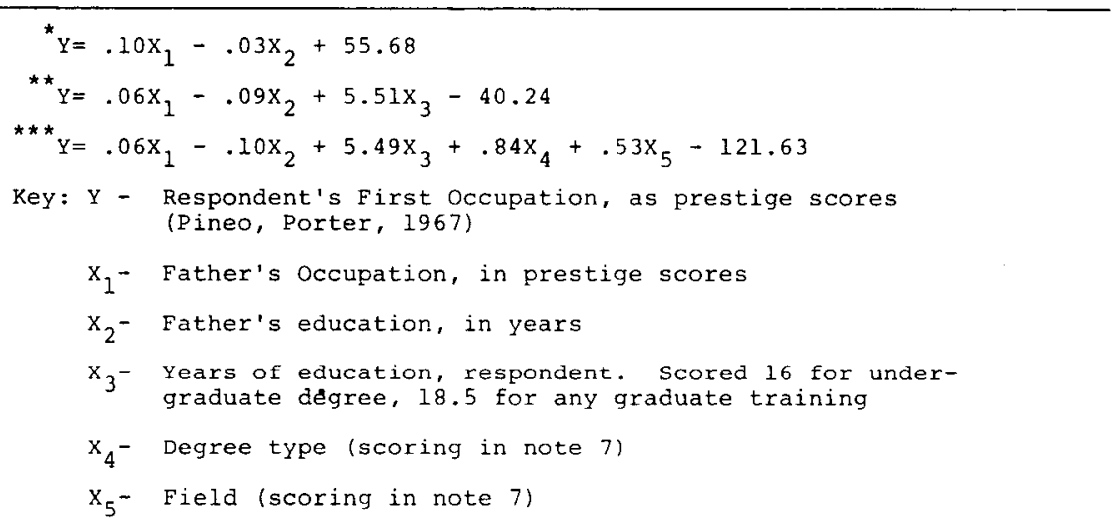

improvement. ${ }^{7}$ It is known that the trend over the years has been towards science over arts degrees, and away from fields of study in the humanities (Harvey, 1974: 117-8). First job SES should have increased in every year, according to these changes alone, but the effect is more than offset by a decline in the ratio of honours to general degrees. The decline in honours degrees may be attributable to the relaxation in entrance standards during the expansion of the university system.

A second assessment of the consequences of background endowments for the attainment of first occupation among the university educated results from duplicating the above analysis using the national mobility sample. Something similar to the four year intervals in the Ontario sample is obtained by classifying birthdates into intervals of four. The probable error in the estimation of graduation year from age leaves comparisons between contiguous cohorts prone to imprecision but the historical range of the data set allows a view of the overall trend over some 40 years. Other procedures in this analysis differ from those followed in the Ontario sample. Occupation in the national sample is coded into Blishen scores instead of prestige scores. The two are, of course, closely related if not fully interchangeable (see Blishen and McRoberts, 1976). The national sample 
allows tabulations for the non-university educated, a reference point useful for assessing the fortunes of the university educated. "University educated" includes those without a completed degree, a group not sampled in the Ontario design. Finally, the design for the national survey contains a fuller inventory of biographical variables. The regression equation for predicting first occupation Blishen score contains respondent's education (measured by years of education and by a dummy variable to distinguish those with a university degree from others), ${ }^{8}$ father's occupation (Blishen score and a dummy variable for fathers who are managers or professionals), father's education (years, and a dummy variable for those holding a degree), number of siblings, respondent's country of birth (effect proportional scoring), and the language respondents first learned to speak (effect proportional scoring). The rationale of the model is that, along with the desideratum of a father of high education and occupational status, it assists chances of worldly success to have been born into a small family, to be Canadian born or from the English-speaking democracies, and to be English-speaking. The procedure was to compute the model for the total population and to differentiate the university educated from others by means of the dummy variable for university degree.

A presentation of observed and predicted mean first occupation Blishen scores appears in Table 3. The actual scores for recent cohorts reveal something of the pattern observed in the Ontario survey. The attainment of high status first occupations reached a peak between the late 1950's and the mid 1960's. By 1966-69, when those born between 1945 and 1948 were reaching age 21 , the average had slipped 4.2 Blishen points over the 1958-61 cohort. As in the Ontario data, the national survey reveals a further decline (5.8 points) between the late 1960's and early 1970's. If there is a long term historical pattern to be revealed in the scores for the university educated in Table 3 it is that in the pre-war years the status level of first jobs taken by graduates did not change greatly over time. The score for $1950-53$, for example, is but one point higher than that 20 years earlier. The exception is the low score (51.0) attained by those turning 21 between 1934 and 1937, a finding it is tempting to attribute to the depression.

Evidence of the class structure among the university educated having become more representative is unconvincing in the national data (and is not presented in a table). The cumulative effect of the inventory of social background factors is to suggest that the trend towards democratization should only be understood in a relative sense, to be compared to the backgrounds of fathers of the non-university educated. Father's occupation and education have essentially remained static over cohorts among the university educated. Among the non-university respondents father's SES has slowly increased over time, and so any democratizing tendency in university recruitment takes the form of exclusion from a trend in the total sample of upgrading in father's status. Only two indicators exhibit an absolute democratization: number of siblings increased marginally during the 1960's among the university educated (while declining among others); the proportion of birthplaces advantageous to SES attainment also declined slightly in each cohort since the early 1960's, while increasing among the non-university educated.

Despite the attempts to enrich the model used for generating expected first occupation scores from the national survey it is (as in the Ontario survey) years of education that proves the most responsive predictor of the actual trends. The trend in first occupation, expected on the basis of changes in ascriptive background variables, is trivial; the prediction 
30 John C. Goyder

Table 3: Observed and Predicted First Job SES, for those with and without university Education, by Age Cohorts, National Sample

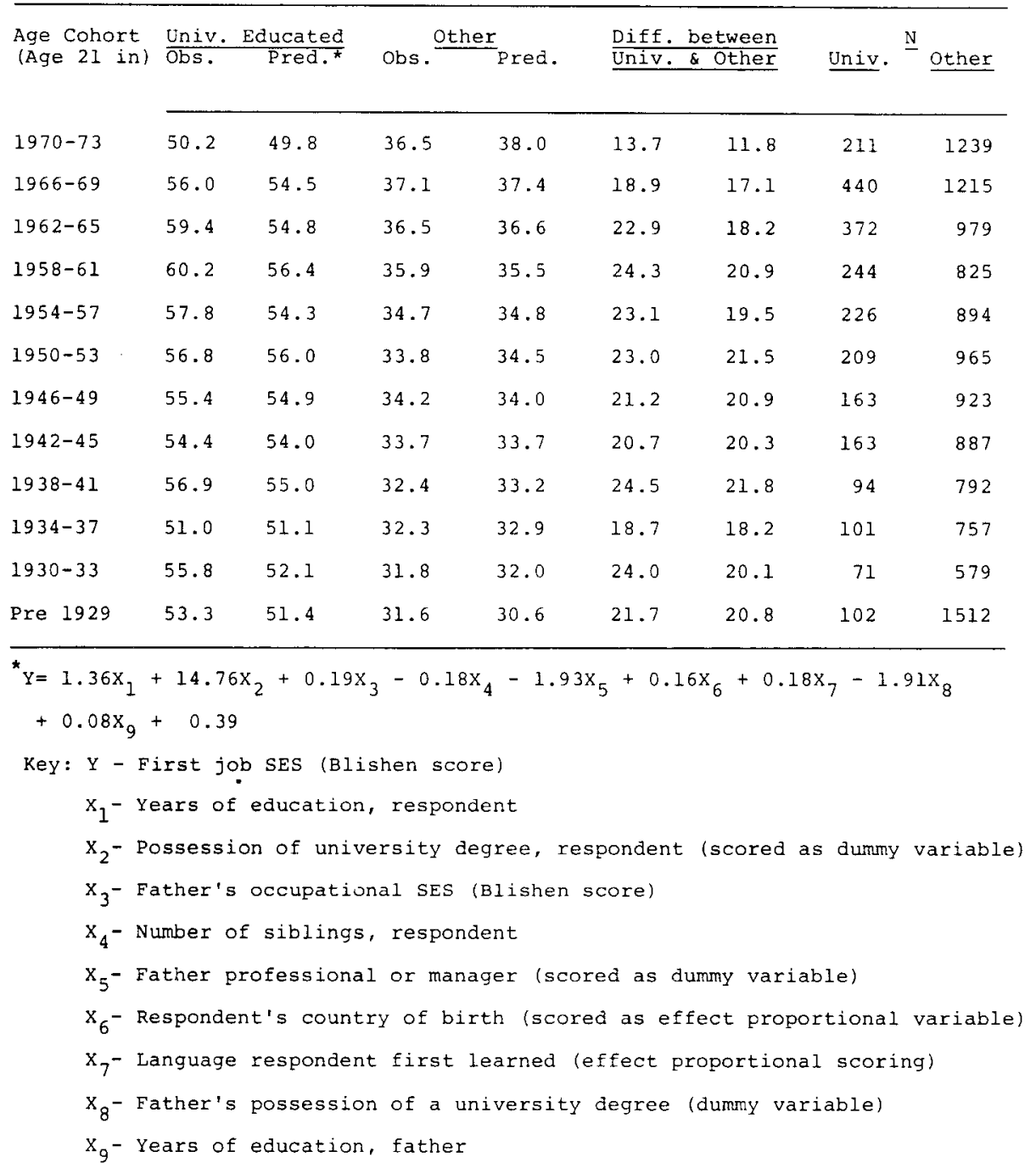

with the full model, including a variable differentiating educational level within the university educated (and non-university) group can be seen in Table 3 , alongside actual scores. The correlation over the twelve pairs of actual-predicted comparisons for the university educated in Table 3 is 0.87 . The model is deficient in anticipating the magnitude of the ascent in mean SES between the 1940's and late 1950's. Further, the decline in first job status among graduating years in the later 1960's is present only in a muted form. The actual decline between 1958-61 and 1966-69 was 4.2 Blishen points. The model shows that only part of the decline - some 2 points - is attributable to changes in background characteristics. 
31 Trends in the Socioeconomic Achievement of the University Educated

Table 4: Nean Eirst Occupation SES by Level of Post-Secondary Education, National Sample

\begin{tabular}{|c|c|c|c|c|c|c|c|}
\hline \multirow{3}{*}{$\begin{array}{l}\text { Age Cohort } \\
\text { Aged } 21 \text { in: }\end{array}$} & \multicolumn{3}{|c|}{ Community College } & \multirow[b]{2}{*}{$\begin{array}{l}\text { Certificate } \\
\text { or diploma }\end{array}$} & \multicolumn{2}{|c|}{ University $\quad$ * } & \multirow{2}{*}{$\begin{array}{l}\text { Professional } \\
\text { degree }\end{array}$} \\
\hline & Some & Completed & Some & & $\begin{array}{l}\text { Bachelor's } \\
\text { degree }\end{array}$ & $\begin{array}{l}\text { Master's, } \\
\text { Doctoraté }\end{array}$ & \\
\hline & & & & & & & \\
\hline $1970-73$ & $\begin{array}{l}41.4 \\
(98)\end{array}$ & $\begin{array}{l}47.4 \\
(109)\end{array}$ & $\begin{array}{l}43.4 \\
(118)\end{array}$ & $\begin{array}{l}49.5 \\
(28)\end{array}$ & $\begin{array}{l}59.3 \\
(67)^{3}\end{array}$ & $\stackrel{*}{(5)}$ & ${ }^{\star}(6)$ \\
\hline $1966-69$ & $\begin{array}{l}38.0 \\
(64)\end{array}$ & $\begin{array}{l}47.5 \\
(84)\end{array}$ & $\begin{array}{l}48.0 \\
(162)\end{array}$ & $\begin{array}{l}52.7 \\
(26)\end{array}$ & $\begin{array}{l}58.4 \\
(209)\end{array}$ & $\begin{array}{l}63.6 \\
(31)\end{array}$ & $\begin{array}{l}70.1 \\
(38)\end{array}$ \\
\hline $1962-65$ & $\begin{array}{l}37.9 \\
(47)^{2}\end{array}$ & $\begin{array}{l}48.5 \\
(57)\end{array}$ & $\begin{array}{l}51.5 \\
(127)\end{array}$ & $\begin{array}{l}50.2 \\
(45)\end{array}$ & $\begin{array}{l}62.2 \\
(113)\end{array}$ & $\begin{array}{l}67.2 \\
(50)\end{array}$ & $\begin{array}{l}67.4 \\
(71)\end{array}$ \\
\hline $1958-61$ & $\begin{array}{l}43.1 \\
(32)\end{array}$ & $\begin{array}{l}49.2 \\
(28)\end{array}$ & $\begin{array}{l}48.6 \\
(72)\end{array}$ & $\begin{array}{l}51.4 \\
(22)\end{array}$ & $\begin{array}{l}63.3 \\
(84)^{3}\end{array}$ & $\begin{array}{l}66.9 \\
(50)\end{array}$ & $\begin{array}{l}66.8 \\
(39)\end{array}$ \\
\hline
\end{tabular}

\footnotetext{
* Not entered because of small base.

** Merged by Statistics Canada, for confidentiality regulations.
}

The model captures the magnitude of the decline in status among the university educated after the 1966-69 cohort. The accuracy of the model supplies a warning, indeed, that some part of the steep drop may be attributable to measurement effects in the sampling of those in their early 20's. The incidence of incomplete degrees is high among this group, and not all those contemplating graduate work would yet have entered (or completed) their programmes. The design of the questionnaire was supposed to prevent people with uncompleted educational careers from answering the first occupation question but probably these safeguards were only partially effective and by the nature of the phenomenon could never be totally successful.

Actual mean first job status among the non-university educated has, Table 3 reveals, risen steadily over the past 40 years. The regression equation predicts the trend, and it is again education that is the important component. Those who do not go to university nevertheless are likely to acquire more education today than a generation ago. In part the trend is an inevitable consequence of school leaving age legislation. The difference in mean status between the university and non-university educated has, as economists in the United States (Freeman, 1976: 21) have found, tended to diminish and the trend is particularly clear (Table 3) for the cohorts from 1958-61 onward. The convergence is in part attributable to the diminished returns on the university degree under unfavourable employment conditions but it is also true that the non-university educated workers have been staying longer in school and in non-university post-secondary education programmes, such as community colleges, and have closed the gap as a consequence.

It might, indeed, be thought that the contemporary labour market has overturned the traditional primacy of the university degree over other forms of post-secondary certification. With some stretching of the case base in the national sample, this issue can be addressed. In Table 4, mean first job SES scores (with N's in parentheses) for the cohorts from 1958 onwards are presented for seven levels of post-secondary education: some community community college, completed community college, some university, certificate 
or diploma from university, Bachelor's degree, Master's or Doctorate degree, professional degree (e.g., M.D., L.L.B., C.A.). Province where the respondent was educated was not ascertained in the survey, and so regional variation in the meaning of community college is undetectable.

It can be observed that the first oc cupations commanded by community college versus university educations have converged in status, but the premium on the Bachelor's degree over the lower forms of education had by no means disappeared by the early 1970's. The community college graduate has borne only a small decline in mean SES over the years (49.2 among those aged 21 between 1958 and 1961, 47.4 in 1970-73). The decline among the university educated with Bachelor's degrees totaled 4 Blishen points, but so large is the initial difference (in 1958-61) between the two levels of qualification that a margin of over 10 Blishen points held for the most recent cohort in the series. Several years have already passed since the national survey was collected (in 1973). One of the contributions of newer surveys will be a cont inued monit oring of the fortunes of university ve rsu s community college gra duates.

\section{ATTAINMENT MODELS FOR COHORTS OF THE UNIVERSITY EDUCATED}

The procedure in the foregoing analysis has been to inquire into the changes in mean first job SES, among diffe rent groups of the university educated, to be expected solely on the basis of changing levels of endowments. Now this assumption is to be relaxed, and variations in the form the sta tus at tainment model assumes for each group will be examined.

Table 5 cont ains an analysis of covariance, testing the stat istical significance of variations over cohorts in the strength of regression of first occupation on father's occupation. This regression describes the deliberately parsimonious model based on the premise, from mobility table an alys is, attributing importance to the over all linkage between the occupational SES of successive gene rations. In the Ontario sample, the test reveals that the slope between father's and son's occupation has not varied, within the bounds of sampling fluctuations, over the four graduation years sampled in the survey. Harvey (1974: 166-7; 1975: 138) has examined the $1960-68$ portion of this data set and concluded that mobility increased over the period. The properties of regression analysis render slope coefficients immune to the simple variety of struct ural upgrading or dow ngrading in the labour force (Hauser, et al., 1975) and capture something close $r$ to a generic "net" or underlying mobility rate. It is mobility defined in this sense which, according to the analysis of covariance test, has not altered; the trends detected by Harvey should be understood as consequences of shifts in the occupation margins of the father-to-son mobility table. Such mobility would occur, for instance, if there were insufficient vacancies for all sons of high status fathers to themselves take high status jobs.

In the national sample the regression of first job on father's occupation is found to interact $(p<.001)$ with coh ort. This, perhaps, is because the hist orical range in the national sample is greater than in the Ontario data. The in teraction effect in the national sample is not trivial. The range in values for slopes is almost .50 points, from $B=-.23$ in $1930-33$ to +.26 in years before 1930 . The interaction (of father's and first occupation with cohort) remains significant when the model is expanded to include the additive effects of father's edu cation and respond ent's years of education. And, the forms of 


\section{Trends in the Socioeconomic Achievement of the University Educated}

status attainment model peculiar to different cohorts at the time of respondent's entry into a first occupation seem to reta in the ir importance even for the current occupation recorded in 1973. This is seen by testing the regression of current occupation on father's occupation for interaction with cohort, an effect which again passes the significance test $(\mathrm{p}<.001)$.

The meaning of the in teraction is not as ea sy to establish as the statistical existence of the effect. The pattern does not conform with the conject ure, described earlier, that ascription becomes tighter under an unfavourable labour market. The tendency, if there is one at all, is the opposite, but the relationship does not seem sufficien tly orderly to support fresh hypothesizing. One is simply left with some hint that under a tight labour market those from low SES families enjoy a compet it ive advantage over others, and the style of analysis ensures that this is more than a mathematically inevitable consequence of the overall decline in graduates' first job SES.

\section{DISCUSSION}

The paper has presented evidence on trends in the level of first job status achieved by successive waves of unive rsity graduates, on background endowments among each group, and on the consequences background has for achievement. The approach was to ask if the sociologist's status attainment mode l, concen trating upon biographical predictors of worldly success, renders comprehensible the recent decline in status a mong the university educated. In both data sets, Edward Harvey's sample of graduat es from Ontario universities and a national sample from a study of occupational mobility in Canada, a model incorporating the variables conventionally though t-approp ria te to occupational analysis achieves some success in predicting the trend.

The proposition that the expansion of the universities during the 1960's resulted in a ge nuine democratization of access shows signs of entering the realm of textbook wisdom (e.g., Tepperman, 1975: 193), but the two samples employed here return something close to a split decision; the sagacity of writers who have suspended judgement on this controversial question is upheld. The class distribution of university students (as opposed to the proportion, from each class, who attend university) is sensitive to changes in socioeconomic structu re itself over time. To compute the SES distribution for the university populations of different deca des since the Second World War gives deceptive results, when taken at face value, because mean SES in the population as a whole has increased over the years. Finding a steady proportion of low SES background university graduates over time offers support of a kind for the democratization thesis. Nevertheless, while it has been obse rved that family background has consequences for occupational attainment even among the university educated, the de mocratization would have had to be e normous before changes over time in levels of family background end owmen ts would account for any important share of the trends in first job attainment.

It is educational differentiation within the university educated that has been identified as the principal means by which a stat us attainment interpretation accounts for the observed decline in graduates' prospects. Stat uses such as father's occupation or education indisputably belong to a class of variable se parate from labour market factors. Settled a generation before offspring enter the labour market, only the most exaggerated of feedback loops could posit that parents plan their own careers in anticipation of developments 


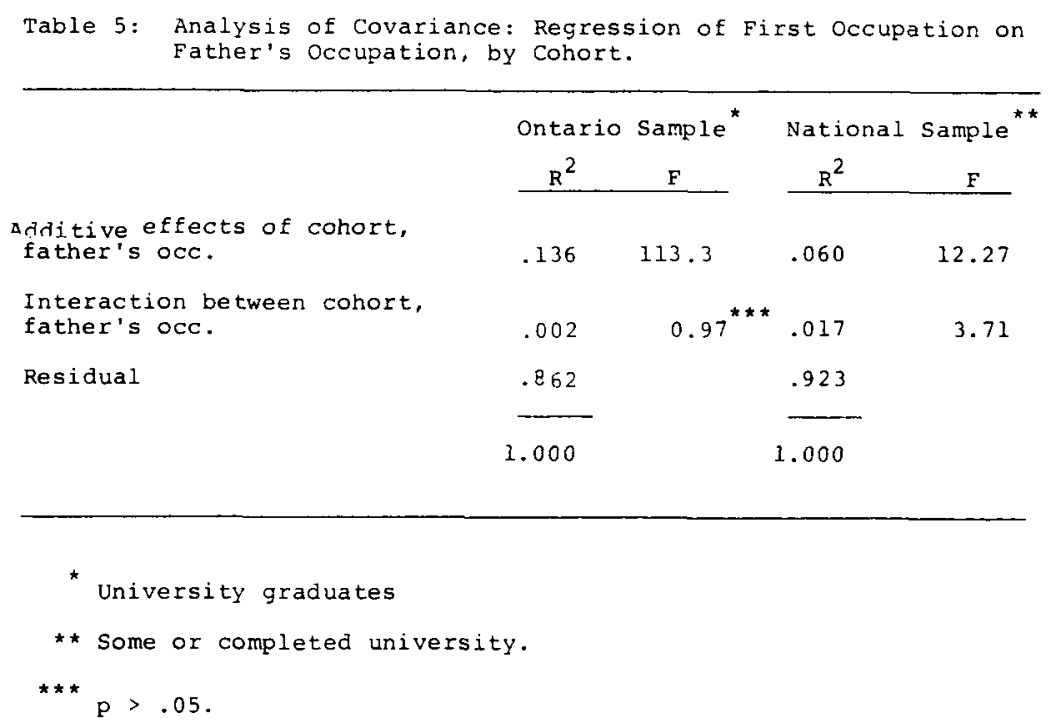

in the labour market to be encountered by their children 20 or 30 years in the future. Education is not so easily catalogued as a biographical versus a labour market variable. The model computed without a control for education (treating all the unive rsity educated as having equiva lent education) should permit the "path" from parental SES, through education, to respondent's SES to be incorporated int o the overall effect of father's occupation and education. Predictions from this model, however, have been se en to be weak. Decisions by those in university about whether they complete their programmes, graduate at the general or honours level, or continue to post-graduate work are no doubt determined by many factors ranging from assessmen ts of the labour market to sheer idiosyncracy. Relaxation of entrance standards into undergra duate programmes is said to have diluted the average level of endowments in I.Q. and scholastic ability. This, a genuinely individualistic factor, is likely to have depressed completion rates. From Harvey (1974: 126) it is known that motives for studying at the post-graduate level fluctuate according to the labour market, but the actual form of the reciprocity is complicated. It has been thought, for instance, that graduate enrollmen ts increase in an unfavourable market because career decisions can thereby be postponed.

In sum, changes in ascriptive endowments among graduates from different years are responsible for at best a minor part of the recent downward trend. The contribution of the sociologist's approach is probably more one of identifying within a formal model an individual level adaptation to market level changes than discovering a class of variable unconnected to the economist's labour market analysis. The status attainment model has suggested that one of the important ways in which an unfavourable labour market becomes translated into consequences for individuals is through the growing disinclination of those with some undergraduate work to fin ish the degree or of those with the completed degree to eschew graduate education. The inseparability of the lab our market environment and individuals' decisions about education is emphasized again as one begins 
to conjecture that in a tight market the very fact that some decide against post-secon dary education helps preserve what is left of the human capital return for others.

The form of analysis that has been presented is not without limitations. Neither survey is a true longitudinal design. The national data were all collected in one year and this creates a bias. Some of those aged 21 (graduating) just before the survey was collected would still be enrolled in post-graduate programmes and so could not yet have taken their first job after completing their education. This inevitably exaggerates the decline in first job status for the most recent cohort. The same dist ortion is present for the Ontario survey. The first three cohorts were all sampled in 1971 and Harvey (1974: 136-8) has discussed the implications. Enrollments in Master's and Doctoral programmes are in fact known from government statistics to have increased during the late 1960's and early 1970's (Statistics Canada, 1977:8) but have probably been offset by a decline in enrollments in shorter courses such as teacher training. The proportion of attempted but uncompleted Bachelor's degrees, less likely to be affected by age cutoffs in the sample design, shows in the national survey a marked increase since the 1950's. It is probable that taking level of university education into account in the status attainment model adjusts both for survey artifact and a genuine deterioration in educational endow ments.

A second limitation concerns the choice of socioeconomic variables. Studying first occupation SES ignores the unemployed, a small group among the university educated (Beach, 1977) but one which may be growing. The sociologist's stress on the distribution of the university educated within a stable hierarchy of occupations necessarily results in a neglect of market induced changes in the hierarchy itself. Occupational income is, for the status attainment analyst, an over-sensitive index of trends in the status of university graduates. An occupational status that constantly shifts with the labour market cannot meaningfully be included in a model stressing the enduring importance of family socioeconomic background.

It is as research design decisions such as these are made that the importance of distinctions between intellectual disciplines is re-discovered. Hybridization across approaches is, to be sure, extensive. Sociologists have begun to include labour market variables in the attainment model. Labour market economists such as Freeman are not unaware of differing levels of endowments or special labour markets for groups such as females and ethnic minorities. And, the models human capital economists design employ many variables familiar to status attainment sociologists, even though the theoretical emphasis is unique. Our view, however, would be that it is the variables that can be formally incorporated into a statistical model that reveal most accurately the basic assumptions of an intellectual school. The logic of the human capital model has it that supply has much to do with the creation of demand and so the labour market need not be central to the statistical analysis carried out within the model. Labour market models could probably be expanded to incorporate some notions of variation in endowments - product differentiation as it might be termed - but it seems likely that interpretive difficulties across units of analysis would mount. Similarly, the labour market variables that have been forced into status attainment models dissipate some of the causal rigour achieved by the ordering of biographical variables in the model. The contribution, beyond statistical interpretation, that the attainment model brings to the debate about under-employment of graduates would seem to lie in the attention it draws to the consequences, malignant 
and benign, of the deliberate commitment after the war to democratize the universities. This emphasis in the debate over universities is genuinely distinct from the human capital stress upon the wealth creating implications of university expansion and the labour market economist's attention to year-to-year equilibrium in the market for the highly educated.

\section{FOOTNOTES}

1. Horan (1978) has argued that the principal difference between an economic and a status attainment approach is that the latter conceives of a pure competition labour market while economists analyze the segmented market. It seems more plausible to argue that status attainment theorists have always held an intuition that the labour market is imperfect. To calculate separate inodels for blacks versus whites, or men versus women is to acknowledge that there is no "assumption of fully open and competitive allocation of individuals to jobs" (Horan, 1978: 538). The contribution of labour market economists has been to articulate the form of the imperfection and clarify the theoretical meaning of variables such as industry.

2. A reminder of the inclination to caricature provided by such summaries of intellectual disciplines is purveyed in Vanfossen's (1979: 118-135) discussion of income inequality in the United States. The "individualistic" interpretation, offered both by functionalist sociologists and by human capital economists is distinguished from the structural viewpoint of the labour market economist and likeminded sociologists.

3. It is not to be expected that the effect would be as marked among the university educated as among a general population. It is known that part of the importance of parental SES is its influence upon the likelihood of entry into university. By concentrating upon the university educated, the effects of parental SES acting through education are partly taken into account. Father's status has, however, been found to retain a relationship with first occupation (and a weaker association with current occupation) independently of education (e.g., Blau and Duncan, 1967).

4. The sample design used by Statistics Canada includes a weight to correct for the oversampling of some groups and the estimated bias attributable to overall nonresponse. The weighted sample sizes are reported here and elsewhere in the paper.

5. The "first occupation" question in the 1973 study reads: "Describe your first full-time job (for pay or profit) after completing your education as indicated above in Question 4." We were endeavouring here to ensure that the first jobs be those following the completion of education so that the linkage between the two could be analyzed as a logical flow, education being regarded as preparing one for entry into the work force. An editing routine was used in order to minimize the problem of educational careers and first jobs that were out of sequence. If respondent's age when starting first job exceeded both the number of years of education he reported, plus a constant of 5 , and the average number of years held by all respondents at the respondent's education level plus the constant, it was concluded that the first job report violated the questionnaire instructions and occurred before the completion of respondent's education. These cases were deleted, eliminating $7 \%$ of the university educated respondents. In the Ontario study, the question asked: "Please list, in the order in which you held them, the three (or fewer if appropriate) most significant jobs you have held since completing your bachelor's degree..."

6. The regression equation used for predictions from the Ontario sample is based on the matrix of correlations from the national survey (except for degree and field). Our rationale is that the precision provided by a large and nationally representative sample should be exploited.

7. The scoring system was to code degree type and programme according to the mean first occupation score held by those in each category. The scores were: General B.A. $=59.2$, Honours B.A. $=61.7$, General B.Sc $=59.8$, Honours B.Sc $=63.3$. Humanities field $=60.3$, Social Science $=58.7$, Natural Science $=62.5$. This method of "effect-proportional" scoring has been used and described by Treiman and Terrell (1975: 751-2). There is a small class effect on degree type (but none on field): those with higher father's SES are most likely to complete an honours degree. 
37 Trends in the Socioeconomic Achievement of the University Educated

8. The procedure in scoring education was to assign estimated years of completed education to respondent's reported level of education. The scores are: none $=1$, some elementary $=4$, elementary $=8$, some high school $=10$, completed secondary school, some non-university post-secondary $=12$, completed non-university post secondary and some community college $=13$, completed community college or some university $=14$, B.A. $=16$, professional degree $=18$, M.A., Ph.D. $=19$.

\section{REFERENCES}

Beach, H.D., "Higher Education and Student Employment Needs," Canadian Journal of Higher Education, 1977, 7 (3), 1.22.

Beck, E.M., Horan, P.M., Tolbert, C.M., "Stratification in a Dual Economy," American Sociological Review, 1978, 43 (5), 704-720.

Blau, P.M., \& Duncan, O.D., The American Occupational Structure. New York: Wiley, 1967.

Blishen, B.R., \& McRoberts, H.A., "A Socio-Economic Index for Occupations in Canada," Canadian Review of Sociology and Anthropology, 1976, 13 (1), 41-53.

Boyd, M., \& McRoberts, H., "Design of the 1973 Canadian National Mobility Study on Occupational and Educational Change in a Generation." Paper read at the North Central Sociological Association Meeting, Windsor, Ontario, May, 1974.

Boyd, M., Goyder, J.C., Jones, F.E., McRoberts, H., Pineo, P.C. \& Porter, J., "Status Attainment in Canada: Findings of the Canadian Mobility Study." forthcoming, Canadian Review of Sociology and Anthropology.

Breton, R. Social and Academic Factors in the Career Decisions of Canadian Youth. Ottawa: Manpower and Immigration, 1972.

Cuneo, C.J. \& Curtis, J.E., "Social Ascription in the Educational and Occupational Status Attainment of Urban Canadians," Canadian Review of Sociology and Anthropology, 1975, 12 (1), 6-24.

Duncan, O.D., Featherman, D.L., \& Duncan, B. Socioeconomic Background and Achievement. New York: Seminar, 1972.

Featherman, D.L., \& Hauser, R.M., "Changes in the Socioeconomic Stratification of the Races, 1962-73," American Journal of Sociology, 1976, 82 (3), 621-651.

Featherman, D.L. \& Hauser, R., The Process of Stratification. New York: Academic Press, 1977.

Forcese, D., The Canadian Class Structure. Toronto: McGraw-Hill Ryerson, 1975.

Freeman, R.B., The Labor Market for College-Trained Manpower. Cambridge, Mass.: Harvard University Press, 1971.

Freeman, R.B., "Overinvestment in College Training?" Journal of Human Resources, 1975, X (3), 287-311.

Freeman, R.B., The Overeducated American. New York: Academic Press, 1976.

Gilbert, S., \& McRoberts, H., "Academic Stratification and Education Plans: A Reassessment," Canadian Review of Sociology and Anthropology, 1977, 14 (1), 34-47.

Handa, M.L., \& Skolnik, M.L., "Empirical Analysis of the Demand for Education in Canada," in S.

Ostry (ed.), Canadian Higher Education in the Seventies. Ottawa: Information Canada, 1972.

Harvey, E.B., Educational Systems and the Labour Market. Toronto: Longman, 1974.

Harvey, E.B., \& Charner, I., "Social Mobility and Occupational Attainments of University Graduates," Canadian Review of Sociology and Anthropology, 1975, 12 (2), 134-149.

Harvey, E.B., \& Lennards, J., "The Changing Nature of Post-Secondary Education: Attitudes, Costs, and Benefits." Report to the Commission on Post-Secondary Education in Ontario, 1970.

Hauser, R.M., Dickinson, P.J., Travis, H.P., \& Koffel, J.N., "Structural Changes in Occupational Mobility Among Men in the United States," American Sociological Review, 1975, 40 (5), 585-598. 
Hodge, R.W., Siegel, P.M., \& Rossi, P.H., "Occupational Prestige in the United States: 1925.1963," in R. Bendix and S.M. I.ipset (eds.), Class, Status, and Power. New York: Free Press, 1966.

Horan, P.M., "Is Status Attainment Research Atheoretical?" American Sociological Review, 1978, $43(4), 534-541$.

Manpower and Immigration, Supply, Demand and Salaries, 1976 Ottawa: Printing and Publishing, 1976.

Ostry, S., The Female Worker in Canada. Ottawa: Dominion Bureau of Statistics, 1968.

Ostry, S., \& Zaidi, M., Labour Economics in Canada. Third Edition. Toronto: Macmillan, 1979.

Pike, R., Who Doesn't Get to University - And Why. Ottawa: Runge Press, 1970.

Pineo, P.C., \& Porter, J., "Occupational Prestige in Canada," Canadian Review of Sociology and Anthropology, 1967, 4 (1), 24-40.

Porter, J., The Vertical Mosaic. Toronto: University of Toronto Press, 1965.

Porter, M., Porter, J., \& Blishen, B., Does Money Matter? Toronto: Institute for Behavioral Research York University, 1973.

Sorokin, P.A., Social and Cultural Mobility. New York: Free Press, 1964 (1927).

Statistics Canada. "Fall Enrolments in Universities, 1975-76." Statistics Canada Catalogue No. 81-204, 1977.

Synge, J., "The Sociology of Canadian Education," in C.N. Ramu and S.D. Johnson (eds.). Introduction to Canadian Society, Toronto: Macmillan, 1976.

Tepperman, L., Social Mobility in Canada. Toronto: McGraw-Hill Ryerson, 1975.

Treiman, D.J., \& Terrell, K., "The Process of Status Attainment in the United States and Great Britain," American Journal of Sociology, 1975, 81 (3), 563-583.

Vanfossen, B.E., The Structure of Social Inequality. Boston: Little, Brown, 1979.

Wolff, K.H., "The Sociology of Knowledge and Sociological Theory," in L. Gross (ed.), Symposium on Sociological Theory. New York: Harper and Row, 1959.

Zsigmond, Z., "Population and Enrolment Trends: 1961-2001." Canadian Journal of Education, 1976, 1 (1), 19-38.

Zsigmond, Z.E., \& Wenass, C.J., Enrolment in Educational Institutions By Province, 1951-2 to 1980-1. Study No. 25, Economic Council of Canada, 1970. 